\title{
Fluticasone propionate attenuates platelet-activating factor-induced gas exchange defects in mild asthma
}

\author{
A.A. Acuña*, J. Gabrijelcic*, E.M. Uribe*, R. Rabinovich*, J. Roca*, J.A. Barberà*, \\ K.F. Chung", R. Rodriguez-Roisin*
}

Fluticasone propionate attenuates platelet-activating factor-induced gas exchange defects in mild asthma. A. A. Acuña, J. Gabrijelcic, E. M. Uribe, R. Rabinovich, J. Roca, J.A. Barberà, K.F. Chung, R. Rodriguez-Roisin. (C)ES Journals Ltd 2002.

ABSTRACT: Inhaled glucocorticosteroids may reduce airway mucosal oedema in acute asthma. Inhaled platelet-activating factor (PAF) provokes pulmonary gas exchange disturbances, similar to those shown in severe asthma, which may be due to increased airway plasma leakage.

This randomized, double-blind, placebo-controlled, crossover study investigated the effects of high doses of inhaled fluticasone propionate (FP) in 12 patients with mild asthma before and after PAF inhalation. Patients were studied before and $12 \mathrm{~h}$ after inhaling FP (6 mg) or placebo (P), and then at 5, 15 and $45 \mathrm{~min}$ after PAF challenge.

Compared with vehicle, FP inhaled before PAF improved forced expiratory volume in one second and respiratory system resistance $(R \mathrm{rs})$, increased peripheral blood neutrophils and reduced eosinophil counts. After PAF, FP enhanced transient neutropenia at $5 \mathrm{~min}$ and facilitated the recovery of oxygen tension in arterial blood (FP: $93 \pm 4 \mathrm{mmHg} ; \mathrm{P}: 83 \pm 4 \mathrm{mmHg}$ ) at $45 \mathrm{~min}$, without influencing the increases in $R$ rs.

In conclusion, the improvement of platelet-activated factor-induced oxygen tension in arterial blood disturbances after fluticasone proprionate suggests that inhaled glucocorticosteroids may possess vasoconstrictor properties in the pulmonary circulation.

Eur Respir J 2002; 19: 872-878.

\begin{abstract}
*Servei de Pneumologia i Allèrgia Respiratòria, Institut Clínic de Pneumologia i Cirurgia Toràcica, Institut $\mathrm{d}^{\prime}$ Investigacions Biomèdiques August $\mathrm{Pi}$ i Sunyer (IDIBAPS), Hospital Clínic, Departament de Medicina, Universitat de Barcelona, Barcelona, Spain. "National Heart and Lung Institute, Imperial College School of Medicine, London, UK.
\end{abstract}

Correspondence: R. Rodriguez-Roisin, Servei de Pneumologia i Allèrgia Respiratòria, Hospital Clínic, Villarroel, 170, 08036 Barcelona, Spain.

Fax: 34932275404

E-mail: roisin@medicina.ub.es

Keywords: Chronic airway diseases, inflammatory mediators, inhaled glucocorticosteroids, neutrophil kinetics, pulmonary gas exchange

Received: August 32001

Accepted after revision December 10 2001

This study was supported by Grant $99 /$ 0135 from the Fondo de Investigación Sanitaria (FIS) and the Comissionat per a Universitats i Recerca de la Generalitat de Catalunya (1999 SGR0228), and a grant-in-aid from GlaxoSmithKline (Research and Development, Greenford, Middlesex, UK and Madrid, Spain). A.A. Acuña was supported by Fundación Gran Mariscal de Ayacucho, Caracas, Venezuela and Instituto de Cooperación Iberoamericana (ICI), Spain. E.M. Uribe was supported by GlaxoSmithKline, Argentina.
Platelet-activating factor (PAF)-induced lung function abnormalities may be predominantly related to airway narrowing due to increased microvascular leakage [1-3]. Like many other putative inflammatory mediators in the lung, PAF provokes vascular hyperaemia and/or engorgement, vasodilatation and increased vascular permeability within the airways, thereby facilitating exudation of protein-rich plasma and cells within and around the airway lumen [4, 5].

The predominant therapeutic site of inhaled glucocorticosteroids is in the airways. However, the potency of the topical glucocorticosteroids used for asthma is usually ranked by measuring local cutaneous vasoconstrictor effects when applied to the skin of healthy individuals [6]. The clinical effects of glucocorticosteroids are mostly explained by their antiinflammatory properties, which are time dependent. Beneficial short-term effects of inhaled glucocorticosteroids in asthma have recently been reported [7-9]. High doses of inhaled flunisolide [7] and fluticasone [8] were superior to placebo $(\mathrm{P})$ in the treatment of acute asthma in adults, and a vasoconstrictor effect of inhaled fluticasone propionate (FP) on bronchial blood flow has been demonstrated in mild intermittent asthmatics $[9,10]$. These effects may be enhanced by the increased vascularity of the bronchial wall, seen 
as part of the airway remodelling process in asthma $[11,12]$, and reduced by inhaled glucocorticosteroids $[9,10,12]$.

The authors hypothesized that inhaled FP, a highly potent selective glucocorticosteroid with a low oral bioavailability [13], could prevent airway plasma leakage provoked by a laboratory-induced model of PAF challenge in patients with mild asthma, thereby leading to improvement in systemic, cellular, and lung function disturbances. Accordingly, the effects of a single high dose of inhaled FP on PAFinduced effects in patients with stable mild asthma were examined.

\section{Methods}

\section{Study population}

Twelve patients with stable mild intermittent asthma (table 1) were recruited from the outpatient department of the Hospital Clínic of Barcelona, which was approved by the Ethics Research Committee of the centre. All patients received financial support for their participation in the study and gave informed written consent after the purpose, risks and potential benefits of the study were explained. The inclusion criteria were: forced expiratory volume in one second (FEV 1$) \geqslant 80 \%$ of predicted (according to the authors' predicted equations [14]) or $\geqslant 1.5 \mathrm{~L}$; positive methacholine challenge (provocative dose causing a $20 \%$ fall in FEV1 $(\mathrm{PD} 20)<1.9 \mu \mathrm{mol})$; positive PAF challenge, as shown by increases in respiratory system resistance $(R \mathrm{rs}) \geqslant 35 \%$ from baseline after PAF bronchoprovocation $(18 \mu \mathrm{g})$, based on previous findings [1-3, 15 , 16]; absence of respiratory infection or exacerbation of asthma within the preceding 6 weeks; no previous regular treatment with oral corticosteroids; absence of any systemic or cardiopulmonary disease other than asthma. Maintenance therapy included shortacting $\beta_{2}$-adrenergics with inhaled glucocorticosteroids (11 patients) and long-acting selective adrenergic agonists (one patient). All subjects were nonsmokers and atopic.

Table 1. - Patients characteristics and baseline lung function

\begin{tabular}{|c|c|}
\hline Subjects $n$ & 12 \\
\hline Sex M/F & $6 / 6$ \\
\hline Age yrs & $24 \pm 1$ \\
\hline FEV1 L & $3.63 \pm 0.18$ \\
\hline FEV1 $\%$ pred & $95 \pm 2$ \\
\hline $\mathrm{FEV} 1 / \mathrm{FVC} \%$ & $82 \pm 2$ \\
\hline$R \mathrm{rs} \mathrm{cmH}_{2} \mathrm{O} \cdot \mathrm{L}^{-1} \cdot \mathrm{s}$ & $3.05 \pm 0.16$ \\
\hline PD20 $($ normal $>1.9 \mu \mathrm{mol})$ & $0.25 \pm 0.02$ \\
\hline $\begin{array}{l}\text { PAF challenge ( } \% \text { increase in } \\
\text { Rrs from baseline) }\end{array}$ & $88 \pm 14$ \\
\hline
\end{tabular}

Data are presented as mean \pm SEM unless otherwise stated. M: male; F: female; FEV1: forced expiratory volume in one second; FVC: forced vital capacity; Rrs: respiratory system resistance; PD20: cumulative dose of methacholine causing a $20 \%$ fall in FEV1; PAF: platelet-activating factor.

\section{Measurements}

Blood samples were collected anaerobically through a catheter inserted into the radial artery. Arterial oxygen pressure $\left(\mathrm{Pa}_{\mathrm{a}} \mathrm{O}_{2}\right)$, carbon dioxide pressure $\left(\mathrm{Pa}, \mathrm{CO}_{2}\right)$ and $\mathrm{pH}$ were analysed in duplicate using standard electrodes and haemoglobin concentration was measured by a co-oximeter (Ciba Corning 860 System; Ciba Corning Diagnostics Corporation, Meadfield, MA, USA). Arterial blood gas measurements were not available in one patient.

Both minute ventilation and respiratory rate were measured using a calibrated Wright spirometer (Respirometer MK8; BOC-Medical, Essex, UK). The alveolar-arterial pressure gradient for oxygen $\left(P \mathrm{~A}-\mathrm{a}, \mathrm{O}_{2}\right)$ was calculated according to the alveolar gas equation assuming a standard respiratory exchange ratio $(\mathrm{r}=0.8)$. Total white cell counts in arterial blood were measured with a Technicon H.1 ${ }^{\text {TM }}$ System (Technicon, Tarytown, New York, NY, USA). The measurement of $R$ rs was performed using the forced oscillation technique and its analysis was restricted to $8 \mathrm{~Hz}$ [1-3]. Three-lead electrocardiogram, heart rate (HR), systemic arterial pressure, and arterial oxygen saturation through a pulse oximeter (HP M1166A; Hewlett-Packard, Boblingen, Germany) were continuously recorded throughout the whole study (HP 7830A Monitor and HP 7754B Recorder, HewlettPackard, Waltham, MA, USA). Concentrations of urinary cysteinyl leukotriene $\mathrm{E}_{4}\left(\mathrm{uLTE}_{4}\right)$, corrected for urinary creatinine, were measured with a validated enzyme immunoassay (EIA) [17]. $\mathrm{uLTE}_{4}$ determinations were not available in two patients.

\section{Study design}

A randomized, double-blinded, placebo-controlled, crossover design was used. All patients were challenged twice, 1 week apart, with PAF after the administra tion of either FP (6 mg, 12 puffs; GlaxoSmithKline, Madrid, Spain) or P (lactose), both given as dry powder from the Accuhaler $\AA$ device (GlaxoSmithKline), while breathing room air. All asthma medication was with-held for $48 \mathrm{~h}$ before arrival to the laboratory on each study day. The evening before each study day, at 20:00 h, Rrs and forced spirometric recordings, venous blood sampling (available in six patients only) and urinary samples for $\mathrm{LTE}_{4}$ measurements were taken. Twelve hours after FP/P administration (08:00 h), all measurements, except urine collection, were repeated, with the addition of arterial blood sampling and ventilatory and haemodynamic recordings. Measurements of $R \mathrm{rs}$ before PAF inhalation were carried out three times (every $0.5 \mathrm{~h}$ ) over a $1.5 \mathrm{~h}$ period and averaged. Patients were then challenged with $18 \mu \mathrm{g}$ PAF (1-0-Hexadecyl-2-acetyl-sn-glycero3-phosphocholine; Novabiochem AG, Laufelfingen, Switzerland) $14 \mathrm{~h}$ after FP and vehicle administration, as previously reported [1-3]. All sets of measurements were taken in duplicate immediately before and after PAF inhalation, in the following sequence: $R$ rs, arterial blood sampling, and ventilatory and haemodynamic recordings. One-hundred and twenty minutes 
after PAF, urine was collected again for $\mathrm{LTE}_{4}$ measurements. All patients tolerated the challenges without major problems.

\section{Statistical analysis}

Results were expressed as mean \pm SEM or $95 \%$ confidence intervals (CI). Changes before (20:00 versus 08:00 h) and after PAF challenge were separately assessed by a two-way repeated measure analysis of variance (ANOVA). Baseline values for PAF challenge were those obtained in the mornings. This model was considered appropriate to the two-period, two-treatment, crossover design used to determine the effect of FP compared with P and allowed for intrasubject comparisons at each time point, as previously shown $[15,16]$. Newman-Keuls multiple range tests were used to determine the significance of paired isotopic variables between $\mathrm{FP}$ and $\mathrm{P}$ at each time point. Statistical significance was set at $\mathrm{p}<0.05$.

\section{Results}

\section{Effects of fluticasone before platelet-activating factor}

Table 1 shows the characteristics and baseline functional measurements of all patients and table 2 includes lung function and haemodynamic findings, peripheral cell counts and $\mathrm{uLTE}_{4}$ concentrations before and after FP and vehicle administration. Compared with $\mathrm{P}$, the inhalation of FP provoked an improvement in airway calibre, as assessed by mild favourable changes in FEV1, either expressed as absolute values $(\mathrm{p}<0.04)$ or $\%$ pred $(\mathrm{p}<0.003)$, and $R$ rs $(\mathrm{p}<0.008)$ (fig. 1 and table 2). Likewise, inhaled FP increased peripheral blood neutrophils $(\mathrm{p}<0.004)$ but reduced eosinophil counts $(\mathrm{p}<0.008)$, without inducing changes in the concentrations of $\mathrm{uLTE}_{4}$ (table 2). The functional and cellular findings during
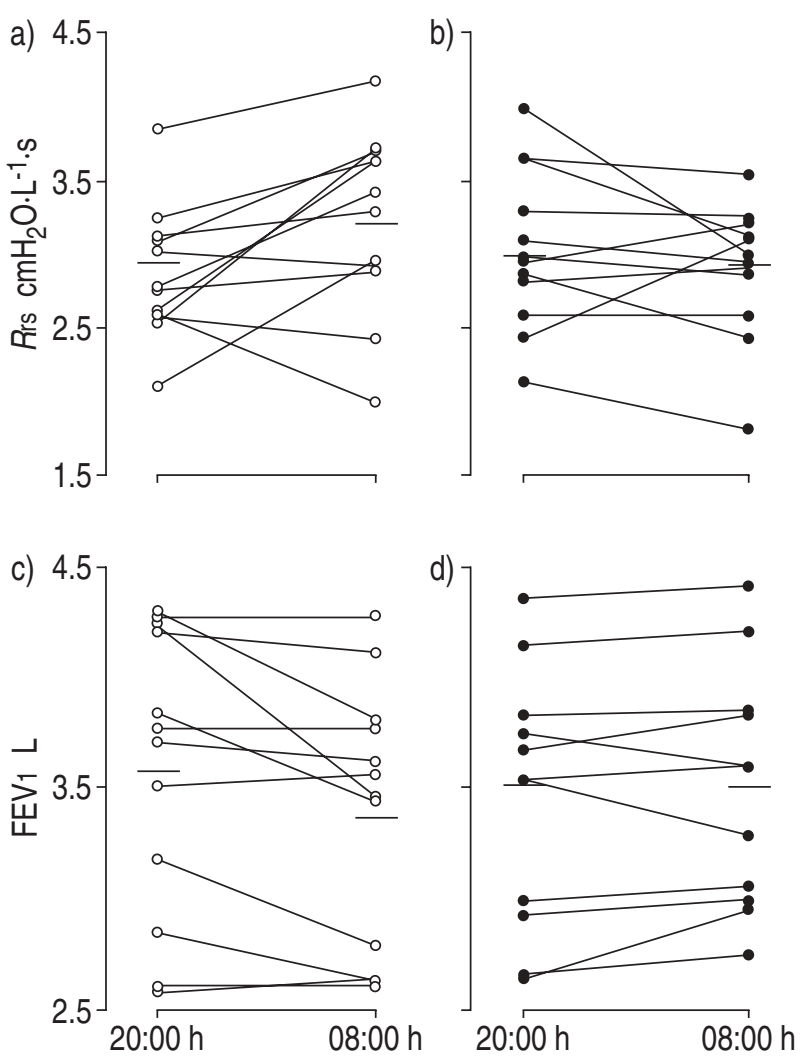

Fig. 1.-Changes in the individual values of resistance of respiratory system (Rrs) (a and b) and forced expiratory volume in one second (FEV1) (c and d) after placebo $(O)$ and fluticasone propionate (-) pretreatment before platelet-activating factor challenge. - : mean values. $\mathrm{p}<0.008$ comparing $R$ rs and $\mathrm{p}<0.04$ comparing FEV1 between placebo and fluticasone groups.

$\mathrm{P}$ administration may be ascribed to the circadian rhythm. There were no differences in ventilatory, haemodynamic, and gas exchange indices between the morning set points after each pre-treatment.

Table 2. - Changes between placebo and fluticasone propionate before platelet-activating factor challenge

\begin{tabular}{|c|c|c|c|c|}
\hline & \multicolumn{2}{|c|}{ Placebo } & \multicolumn{2}{|c|}{ Fluticasone } \\
\hline & $20: 00 \mathrm{~h}$ & 08:00 h & $20: 00 \mathrm{~h}$ & 08:00 h \\
\hline FEV1 L & $3.58 \pm 0.18$ & $3.39 \pm 0.17$ & $3.51 \pm 0.17$ & $3.54 \pm 0.15^{\#}$ \\
\hline FEV1 $\%$ pred & $94 \pm 3$ & $89 \pm 3$ & $92 \pm 3$ & $100 \pm 2^{\bullet}$ \\
\hline$R \mathrm{rs} \mathrm{cmH}_{2} \mathrm{O} \cdot \mathrm{L}^{-1} \cdot \mathrm{s}$ & $2.86 \pm 0.13$ & $3.23 \pm 0.18$ & $3.03 \pm 0.15$ & $2.89 \pm 0.13^{+}$ \\
\hline$V^{\prime} \mathrm{E} \mathrm{L} \cdot \mathrm{min}^{-1}$ & $9 \pm 1$ & $10 \pm 1$ & $11 \pm 1$ & $10 \pm 1$ \\
\hline $\mathrm{RR} \min ^{-1}$ & $15 \pm 1$ & $14 \pm 1$ & $15 \pm 1$ & $14 \pm 1$ \\
\hline$P \mathrm{a}, \mathrm{O}_{2} \mathrm{mmHg}$ & & $96 \pm 4$ & & $96 \pm 3$ \\
\hline $\mathrm{Pa}, \mathrm{CO}_{2} \mathrm{mmHg}$ & & $40 \pm 1$ & & $38 \pm 1$ \\
\hline$P$ A-a, $\mathrm{O}_{2} \mathrm{mmHg}$ & & $8 \pm 3$ & & $8 \pm 2$ \\
\hline $\mathrm{pH}$ & & $7.42 \pm 0.01$ & & $7.43 \pm 0.01$ \\
\hline HR $\min ^{-1}$ & & $67 \pm 3$ & & $64 \pm 3$ \\
\hline$P_{\mathrm{s}} \mathrm{mmHg}$ & & $102 \pm 3$ & & $98 \pm 4$ \\
\hline Neutrophils $\times 10^{9} \cdot \mathrm{L}^{-1}$ & $3.35 \pm 0.33$ & $2.34 \pm 0.15$ & $3.57 \pm 0.38$ & $3.98 \pm 0.51^{\S}$ \\
\hline Eosinophils $\times 10^{9} \cdot \mathrm{L}^{-1}$ & $0.44 \pm 0.10$ & $0.41 \pm 0.10$ & $0.45 \pm 0.10$ & $0.21 \pm 0.02^{+}$ \\
\hline $\mathrm{uLTE}_{4} \mathrm{pg} \cdot \mathrm{mg}$ creatinine $^{-1}$ & $413 \pm 95$ & $305 \pm 34$ & $241 \pm 31$ & $355 \pm 104$ \\
\hline
\end{tabular}

Data are presented as mean \pm SEM. FEV1: forced expiratory volume in one second; Rrs: respiratory system resistance; $V^{\prime}$ E: minute ventilation; RR: respiratory rate; $P \mathrm{a}, \mathrm{O}_{2}$ : oxygen tension in arterial blood; $P \mathrm{a}, \mathrm{CO}_{2}$ : carbon dioxide tension in arterial blood; $P \mathrm{~A}-\mathrm{a}, \mathrm{O}_{2}:$ alveolar-arterial oxygen pressure gradient; HR: heart rate; $P_{\mathrm{s}}$ : systemic arterial pressure; uLTE urinary leukotriene $\mathrm{E}_{4}{ }^{*}{ }^{\#}: \mathrm{p}<0.04{ }^{\uparrow}: \mathrm{p}<0.003{ }^{+}$: $\mathrm{p}<0.008$; ${ }^{\text {s: }} \mathrm{p}<0.004$ 


\section{Effects of platelet-activating factor after vehicle}

Effects of PAF after vehicle are shown in table 3 and figure 2. Ten patients noticed facial flushing, 11 felt shortness of breath, and six coughed immediately after PAF challenge. Five min after PAF, $R$ rs increased by $73 \%$ (from $3.23 \pm 0.18$ to $5.60 \pm 0.45 \mathrm{cmH} \mathrm{O}_{2} \cdot \mathrm{L}^{-1} \cdot \mathrm{s}$, $\mathrm{p}<0.01$ ), $\quad \mathrm{Pa}, \mathrm{O}_{2}$ decreased by $23 \%$ (from $96 \pm 4$ to $74 \pm 2 \mathrm{mmHg}$ ), $\quad P A-\mathrm{a}, \mathrm{O}_{2}$ increased (from $8 \pm 3$ to $26 \pm 3 \mathrm{mmHg}, \mathrm{p}<0.001)$, and peripheral blood neutrophils decreased (from $2.76 \pm 0.30$ to $1.66 \pm 0.36 \times 10^{9} \mathrm{~L}^{-1}$, $\mathrm{p}<0.01)$. This neutropenia was followed by a rebound neutrophilia at 15 and $45 \mathrm{~min}(4.47 \pm 0.58$ and $4.82 \pm$ $0.69 \times 10^{9} \mathrm{~L}^{-1}$, respectively, $\mathrm{p}<0.05$ ). Both ventilatory and haemodynamic variables and $\mathrm{Pa}, \mathrm{CO}_{2}$ and arterial $\mathrm{pH}$ remained unchanged.

\section{Effects of platelet-activating factor after fluticasone propionate}

Effects of PAF after FP are shown in table 3 and figure 2. Pretreatment with FP did not modify or abolish PAF-induced systemic effects: 10 patients noticed facial flushing, 11 shortness of breath, and three cough. Inhaled FP, as compared with vehicle, enhanced the PAF-induced decrease in circulating neutrophils at $5 \mathrm{~min}$ (from $3.93 \pm 0.40$ to $1.71 \pm$ $0.43 \times 10^{9} \mathrm{~L}^{-1} ; \mathrm{FP}-57 \%$; P $-40 \%$; $\left.<0.05\right)$, whereas the rebound neutrophilia observed at 15 and $45 \mathrm{~min}$ (5.20 \pm 0.61 and $5.56 \pm 0.67 \times 10^{9} \mathrm{~L}^{-1}$, respectively) did not differ from that shown after P. Moreover, FP inhalation exhibited modest but significantly greater $\mathrm{Pa}_{\mathrm{a}} \mathrm{O}_{2} \quad$ (FP $\left.93 \pm 4 \mathrm{mmHg} ; \quad \mathrm{P} \quad 83 \pm 4 \mathrm{mmHg} ; \quad \mathrm{p}<0.01\right)$ (fig. 3) and lower PA-a, $\mathrm{O}_{2}$ (FP $11 \pm 3 \mathrm{mmHg}$; P $18 \pm$ $3 \mathrm{mmHg} ; \mathrm{p}<0.02)$ values at $45 \mathrm{~min}$, as compared with P. Compared to baseline $( \pm 1 \mathrm{mmHg})$ (fig. 3), mean $P a, \mathrm{O}_{2}$ after $\mathrm{P}$ was reduced in eight patients $(-18.3 \pm$ $4.3 \mathrm{mmHg})$, was similar in two patients $(-0.9 \mathrm{mmHg})$, and increased in the remaining patient $(4.4 \mathrm{mmHg})$. Conversely, $\mathrm{Pa}, \mathrm{O}_{2}$ after $\mathrm{FP}$ was reduced in five patients $(-11.7 \pm 5.9 \mathrm{mmHg})$ and increased in the other six
(5.0 $\pm 0.9 \mathrm{mmHg})$. Remarkably, there were no differences in the increases in $R$ rs after PAF between the two interventions. The significant increase in $\mathrm{uLTE}_{4}$ concentration observed after PAF inhalation in the FP arm (from $355 \pm 104$ to $1,608 \pm 352 \mathrm{pg} \cdot \mathrm{mg}^{-1}$ ) was not different from that measured after P (from $305 \pm 34$ to $\left.1,421 \pm 401 \mathrm{pg} \cdot \mathrm{mg}^{-1}, \mathrm{p}<0.0001\right)$.

\section{Discussion}

In this study, three main effects of administration of a single high dose of inhaled FP in patients with mild intermittent asthma were observed. Firstly, FP to some degree prevented the diurnal fall in bronchial tone. Secondly, immediately after PAF challenge, there was a more pronounced reduction in circulating neutrophils without differences in the subsequent rebound neutrophilia. Finally, FP attenuated gasexchange defects by the end of PAF challenge, as shown by a greater recovery of arterial oxygenation, without modifying the bronchoconstrictor response.

In this study, the effects of FP $12 \mathrm{~h}$ after inhalation were investigated following a previous preliminary study that examined the inhalation of low-to-high doses of budesonide $(\leqslant 1,600 \mu \mathrm{g})$ in patients with mild asthma [18]. In the study by Le Merre et al. [18], the inhaled glucocorticosteroid improved lung function maximally at $12-14 \mathrm{~h}$. In addition, the authors own preliminary studies, including inert gas measurements, showed no effects of FP when studied at $2 \mathrm{~h}$, using 2 and $6 \mathrm{mg}$, and $6 \mathrm{~h}$, using $6 \mathrm{mg}$ (data not shown). There is evidence of diurnal variation in FP pharmacokinetics, with higher than expected plasma drug concentrations in the morning than in the evening [19]. In this study, a high dose of FP (6 mg) was used, which was likely to contribute to systemic levels. Challenge with PAF, a mediator that may be involved in the pathogenesis of asthma, causes moderateto-severe gas exchange deterioration $[1-3,20]$, similar to that seen in spontaneously-occurring acute asthma. This indicates that the principal mechanism of

Table 3. - Changes induced by platelet-activating factor after placebo $(P)$ and fluticasone propionate (FP) pretreatments

\begin{tabular}{|c|c|c|c|c|}
\hline & $5 \mathrm{~min}$ & $15 \mathrm{~min}$ & $45 \mathrm{~min}$ & p-values ${ }^{\#}$ \\
\hline \multicolumn{5}{|c|}{$R \mathrm{rs} \mathrm{cmH}{ }_{2} \mathrm{O} \cdot \mathrm{L}^{-1} \cdot \mathrm{s}$} \\
\hline $\mathrm{P}$ & $2.38(1.59-3.16)$ & $1.80(0.75-2.85)$ & $0.89(0.28-1.52)$ & \multirow[t]{2}{*}{ NS } \\
\hline $\mathrm{FP}$ & $2.93(1.58-4.27)$ & $1.83(0.89-2.76)$ & $0.82(0.38-1.26)$ & \\
\hline \multicolumn{5}{|c|}{$\mathrm{Pa}_{\mathrm{a}} \mathrm{O}_{2} \mathrm{mmHg}$} \\
\hline $\mathrm{PP}$ & $\begin{array}{l}-22(-29-16) \\
-22(-27-16)\end{array}$ & $\begin{array}{l}-20(-27-12) \\
-19(-25-12)\end{array}$ & $\begin{array}{l}-13(-21--4) \\
-3^{\oplus}(-9-4)\end{array}$ & 0.02 \\
\hline \multicolumn{5}{|c|}{$P \mathrm{~A}-\mathrm{a}, \mathrm{O}_{2} \mathrm{mmHg}$} \\
\hline $\begin{array}{l}\mathrm{P} \\
\mathrm{FP}\end{array}$ & $\begin{array}{l}18(11-25) \\
21(14-28)\end{array}$ & $\begin{array}{l}15(9-22) \\
16(9-23)\end{array}$ & $10(2-17)$ & 0.01 \\
\hline \multicolumn{5}{|c|}{ Neutrophils $\times 10^{9} \cdot \mathrm{L}^{-1}$} \\
\hline $\begin{array}{l}\mathrm{P} \\
\mathrm{FP}\end{array}$ & $\begin{array}{r}-1.09(-1.79-0.39) \\
-2.21^{\oplus}(-3.21-1.22)\end{array}$ & $\begin{array}{l}2.81(1.32-4.29) \\
3.49(1.66-5.32)\end{array}$ & $\begin{array}{l}3.19(1.45-4.95) \\
3.85(1.92-5.78)\end{array}$ & 0.03 \\
\hline \multicolumn{5}{|c|}{ Eosinophils $\times 10^{9} \cdot \mathrm{L}^{-1}$} \\
\hline $\begin{array}{l}\mathrm{P} \\
\mathrm{FP}\end{array}$ & $\begin{array}{l}-0.17(-0.30-0.05) \\
-0.10(-0.17-0.04)\end{array}$ & $\begin{array}{l}0.11(0.04-0.18) \\
0.08(0.03-0.14)\end{array}$ & $\begin{array}{l}0.12(0.03-0.22) \\
0.11(0.04-0.16)\end{array}$ & NS \\
\hline
\end{tabular}

Data are presented as mean with $95 \%$ confidence intervals in parentheses. $R$ rs: respiratory system resistance; $P_{\mathrm{a}}, \mathrm{O}_{2}$ : oxygen tension in arterial blood; $P \mathrm{~A}-\mathrm{a}, \mathrm{O}_{2}$ : alveolar-arterial oxygen pressure gradient. ${ }^{\#}$ : significance of the interaction between the effects of PAF challenge and after pretreatment; ${ }^{\uparrow}: \mathrm{p}<0.05$, significantly different from $\mathrm{P}$. 

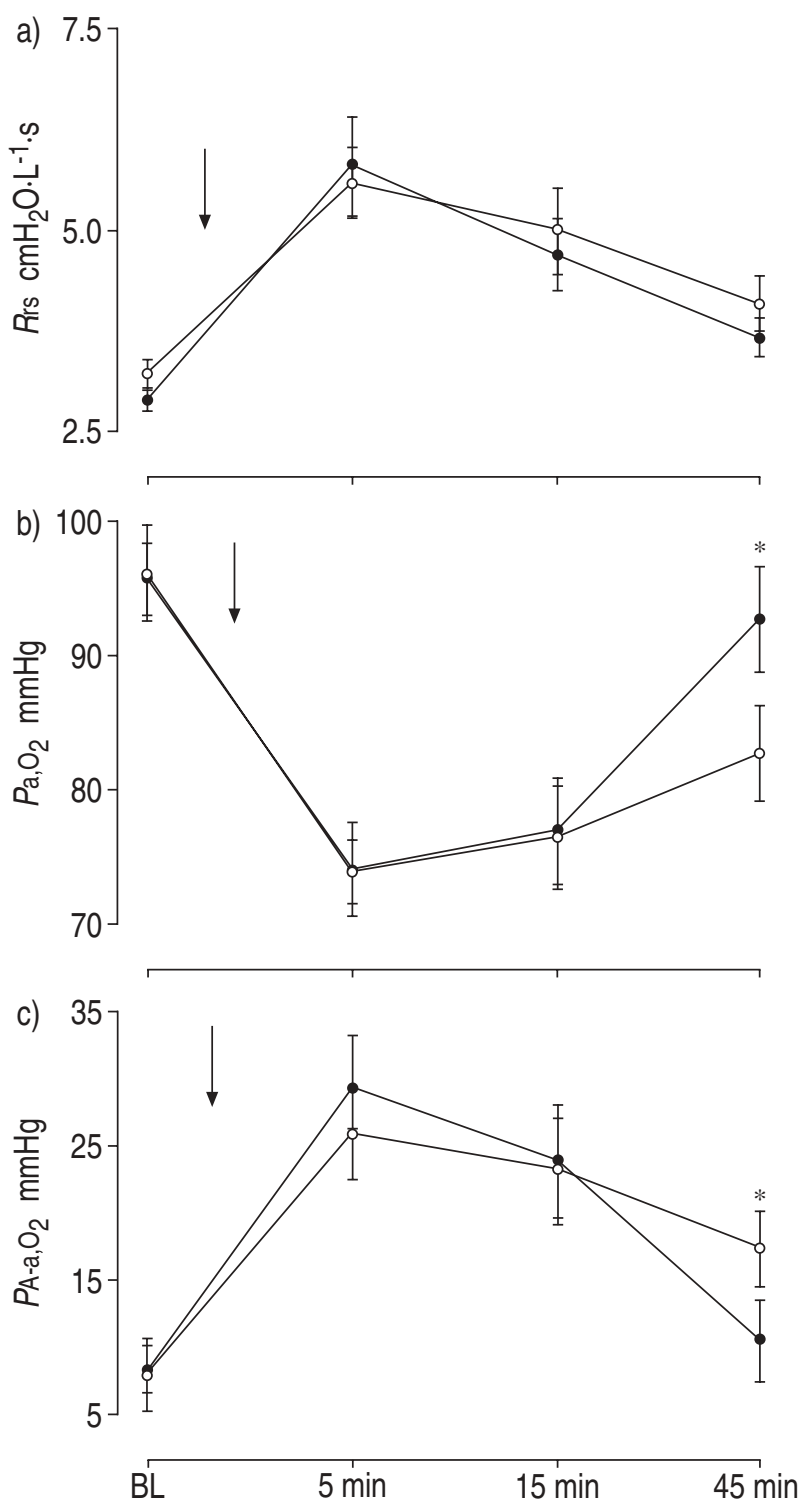

Fig. 2. - The time course of resistance of a) the respiratory system $(R \mathrm{rs})$, b) oxygen tension in arterial blood $\left(P_{\mathrm{a}}, \mathrm{O}_{2}\right)$ and c) the alveolar-arterial oxygen pressure gradient $\left({\left.\mathrm{PA}-\mathrm{a}, \mathrm{O}_{2}\right)}\right)$ at baseline $(\mathrm{BL})$ and at 5, 15, and $45 \mathrm{~min}$ after inhaled platelet-activating factor $(\mathrm{PAF}) . \bigcirc$ : pretreatment with placebo; $\bullet$ : pretreatment with flucticasone propionate; arrows: PAF challenge. *: $\mathrm{p}<0.05$ between placebo and fluticasone propionate.

PAF-induced arterial hypoxaemia, i.e. ventilation perfusion inequalities, could result more from increased vascular permeability than from bronchoconstriction per se [2, 20].

The authors suggest that the three principal effects of FP observed in the current study may be related to the pharmacological properties of inhaled glucocorticosteroids.

Firstly, the bronchodilator effect before PAF challenge could be due to the anti-inflammatory effects of the drug exerted on the bronchial mucosa, although a vasoconstrictor effect on bronchial blood flow cannot be disregarded (see later) $[9,10]$.

Secondly, FP enhanced the peripheral neutropenia
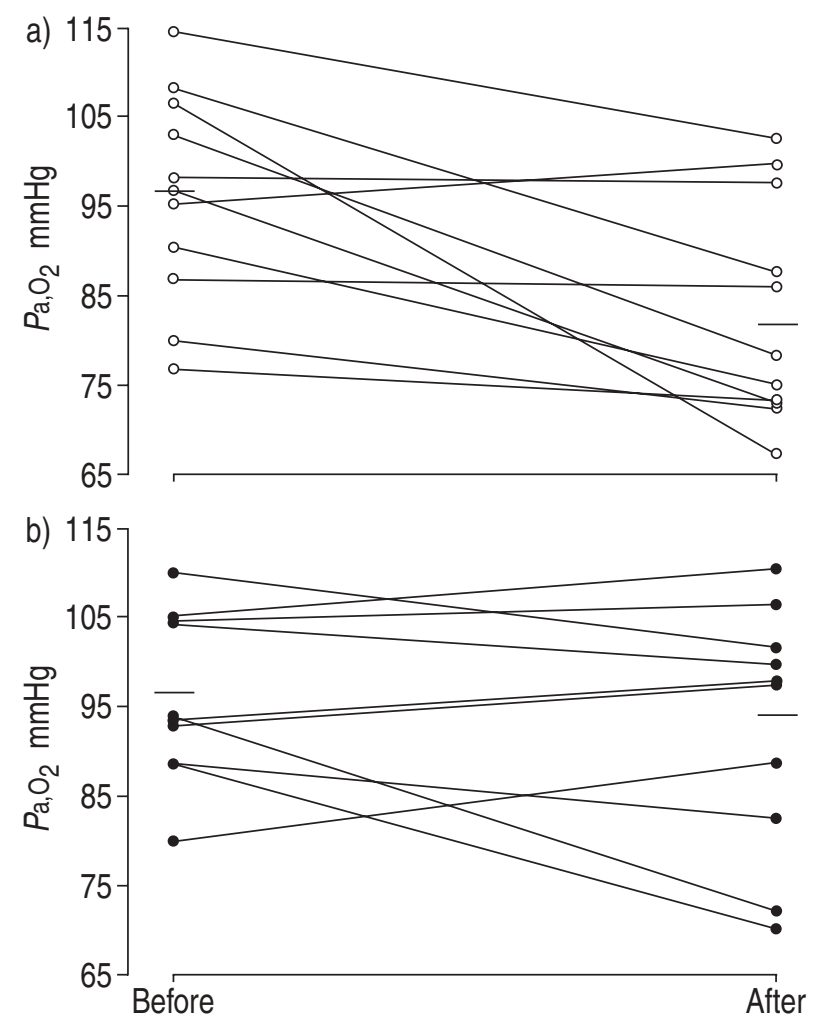

Fig. 3.-Individual changes in oxygen tension in arterial blood $\left(\mathrm{Pa}, \mathrm{O}_{2}\right)$ after placebo $(\mathrm{O})$ and fluticasone propionate $(\Theta)$, before (and after each pretreatment) and $45 \mathrm{~min}$ after platelet-activating factor challenge. - - mean values. $\mathrm{p}<0.01$ comparing placebo and fluticasone.

usually caused by PAF. The authors surmize that FP before PAF facilitated the release of neutrophils from the bone marrow and that these new neutrophils might be less mature and more rigid, i.e. less deformable, and possibly larger than neutrophils that have been circulating. All other things being equal, this would favour a more pronounced retention in the lung after PAF challenge $[21,22]$. Inhaled PAF provokes considerable airway neutrophilia in asthmatics [21, 23] and neutrophilic airway inflammation has been shown to be predominant in persistent asthma [24]. However, glucocorticosteroids do not reduce neutrophilic airway disease inflammation [25] and airway neutrophilia could even persist through glucocorticosteroid-induced inhibition of neutrophil apoptosis [26]. Thus, FP is unlikely to modulate the PAF-induced airway response mediated in part by the release of leukotrienes [15].

Thirdly, the authors hypothesize that the late PAFinduced pulmonary gas exchange amelioration in the FP arm may reflect a predominant vasoconstrictor effect on the pulmonary circulation, possibly facilitating a better alveolar ventilation to pulmonary blood flow balance. As shown in previous studies with other interventions $[2,15,16]$, the lack of an earlier beneficial $\mathrm{Pa}, \mathrm{O}_{2}$ response after $\mathrm{PAF}$ may be due to the intense severity of lung function abnormalities at the nadir of the challenge, not offset by the high doses of FP given. It has been convincingly shown that ventilation perfusion mismatch instantly caused by 
PAF, steadily recovers as the effects of PAF vanish, with a trend toward baseline values by $45 \mathrm{~min}$ [1-3, 15, 16]. The latter finding is at variance with the attenuation of arterial hypoxaemia shown at the end of this study in the FP arm. By contrast, PAF-induced systemic effects and increases in both Rrs and $\mathrm{uLTE}_{4}$ concentrations were not affected throughout the study period, without differences between the two interventions. These negative findings may indicate that FP could not exert a beneficial effect against PAFinduced airway inflammation, which can be mediated, at least in part, by an ongoing endogenous release of leukotrienes [15]. However, complementary bronchial vasoconstriction cannot be overlooked $[9,10]$, as the methodology used for the assessment of PAF-induced increases in total $R$ rs may be less sensitive than gas exchange measurements in detecting an effect on airway vasculature.

The proposed mechanisms of inhaled glucocorticosteroids include upregulation of selective $\beta$-adrenergic receptors, vasoconstriction of the mucosa and decreased wall oedema within the airway [27]. However, the rapid onset of the clinical response in some of these clinical studies [7,9] would indicate that some beneficial effects of glucocorticosteroids may occur very rapidly, while other effects may occur very slowly, requiring a minimum of 6-12 h after medication [28]. MCFADDEN [29] postulated that the effects of flunisolide in patients with acute asthma [7] could result from a nonspecific generic phenomenon common to topical steroids, thereby causing substantial vasoconstriction in the larger airways and modifying, at least in part, some of the pathophysiological components of airway narrowing in bronchial asthma. A transient short-term vasoconstrictor effect in the airway mucosa has recently been demonstrated in mild intermittent asthmatics, after moderate-tohigh doses of inhaled FP [9] and after a 2-week course of moderate doses of FP [10]. Glucocorticoid-induced bronchial vasoconstriction could be related to noradrenaline uptake inhibition by nonneuronal cells, that may facilitate increased noradrenaline concentration at $\alpha$-adrenergic receptors [30].

However, the precise pathogenic mechanism through which inhaled glucocorticosteroids cause bronchial vasoconstriction remains to be elucidated. It has been postulated that this vascular response may reflect a nongenomic mode of action [9, 27] related to stimulation of noradrenergic neurotransmission. However, glucocorticosteroids do not exhibit direct noradrenergic properties. Airway mucosal blood flow is increased in stable asthmatics $[9,10,12,31]$. These observations indicate that inhaled glucocorticosteroids, especially at higher doses, may downregulate airway wall vascularity [12] and restore downregulation of $\beta$-adrenergic agonist-mediated response in patients with asthma $[9,10]$, hence reflecting their anti-inflammatory properties $[10,12]$.

In conclusion, the authors have shown that a single administration of a high dose of inhaled fluticasone propionate facilitates a better recovery of decreased oxygen tension in arterial blood in a laboratoryinduced model of bronchoconstriction caused by platelet-activating factor in mild asthmatics. High doses of this inhaled glucocorticosteroid may attenuate gas exchange defects provoked by plateletactivating factor, by inducing a vasoconstrictor effect within the pulmonary circulation, similar to that shown with a lower dose of fluticasone propionate in the bronchial blood flow compartment. Even though there is an effect of fluticasone propionate on wall oedema and/or bronchial vascular engorgement in peripheral airways with or without redistribution of platelet-activating factor, deposition within the airways cannot be overlooked.

\section{References}

1. Rodriguez-Roisin R, Félez MA, Chung KF, et al. Platelet-activating factor causes ventilation-perfusion mismatch in humans. J Clin Invest 1994; 93: 188-194.

2. Díaz $\mathrm{O}$, Barberà JA, Marrades R, Chung KF, Roca J, Rodriguez-Roisin R. Inhibition of PAF-induced gas exchange defects by beta-adrenergic agonists in mild asthma is not due to bronchodilation. Am J Respir Crit Care Med 1997; 156: 17-22.

3. Félez MA, Roca J, Barberà JA, et al. Inhaled platelet activating factor worsens gas exchange in mild asthma. Am J Respir Crit Care Med 1994; 150: 369373.

4. O'Donell SR, Barnett JK. Microvascular leakage due to platelet-activating factor in guinea pig trachea and bronchi. Eur J Pharmacol 1987; 138: 385-386.

5. Yager DJ, Butler J, Bastacki J, Israel E, Smith G, Drazen JM. Amplification of airway constriction due to liquid filling of airway interstices. J Appl Physiol 1989; 66: 2873-2884.

6. McKenzie AW, Stoughton RB. Method for comparing percutaneous absorption of steroids. Arch Dermatol 1962; 86: 608-610.

7. Rodrigo G, Rodrigo C. Inhaled flunisolide for acute severe asthma. Am J Respir Crit Care Med 1998; 157: 698-703.

8. Levy ML, Stevenson C, Maslen T. Comparison of short courses of oral prednisolone and fluticasone propionate in the treatment of adults with acute exacerbations of asthma in primary care. Thorax 1996; 51: 1087-1092.

9. Kumar DS, Brieva JL, Danta I, Wanner A. Transient effect of inhaled fluticasone on airway mucosal blood flow in subjects with and without asthma. Am J Respir Crit Care Med 2000; 161: 918-921.

10. Brieva JL, Danta I, Wanner A. Effect of an inhaled glucocorticosteroid on airway mucosal blood flow in mild asthma. Am J Respir Crit Care Med 2000; 161: 293-296.

11. $\mathrm{Li} \mathrm{X}$, Wilson JM. Increased vascularity of the bronchial mucosa in mild asthma. Am J Respir Crit Care Med 1997; 156: 806-809.

12. Orsida BE, Li X, Hickey B, Thien F, Wilson JW, Walters EH. Vascularity in asthmatic airways: relation to inhaled steroid dose. Thorax 1999; 54: 289-295.

13. Johnson M. Pharmacodynamics and pharmacokinetics of inhaled glucocorticoids. J Allergy Clin Immunol 1996; 97: 169-176.

14. Roca J, Burgos F, Sunyer J, et al. Reference values for forced spirometry. Eur Respir J 1998; 11: 1354-1362.

15. Gómez FP, Iglesia R, Roca J, Barberà JA, Chung KF, Rodriguez-Roisin R. The effects of 5-lipoxygenase 
inhibition by zileuton on platelet-activating factorinduced pulmonary abnormalities in mild asthma. Am J Respir Crit Care Med 1998; 157: 1559-1564.

16. Gómez FP, Roca J, Barberà JA, Chung KF, Peinado VI, Rodriguez-Roisin R. Effect of a platelet-activating factor (PAF) antagonist, SR 27417A, on PAF-induced gas exchange abnormalities in mild asthma. Eur Respir $J$ 1998; 11: 835-839.

17. Kumlin M, Stensvad F, Larsson L, Dahlén B, Dahlén SE. Validation and application of a new simple strategy for measurements of leukotriene $\mathrm{E}_{4}$ in human urine. Clin Exp Allergy 1995; 25: 467-479.

18. Le Merre C, Bengtsson T, Carlholm M, Ostinelli J. Effect on lung function and inflammatory markers of single-doses of inhaled budesonide in asthmatics. Am J Respir Crit Care Med 1997; 155: A352.

19. Minto C, Li B, Tattan B, Brown K, Seale JP, Donnelly R. Pharmacokinetics of epimeric budesonide and fluticasone propionate after repeat dose inhalation intersubject variability in systemic absorption from the lung. Br J Clin Pharmacol 2000; 50: 116-124.

20. Rodriguez-Roisin R. Acute severe asthma: pathophysiology and pathobiology of gas exchange abnormalities. Eur Respir J 1997; 10: 1359-1371.

21. Wardlaw AJ, Chung KF, Moqbel R, et al. Effects of inhaled PAF in humans on circulating and bronchoalveolar lavage fluid neutrophils. Relationship to bronchoconstriction and changes in airway responsiveness. Am Rev Respir Dis 1990; 141: 386-392.

22. Van Eiden FJ, Kitigawa Y, Klut ME, Lawrence E, Hogg JC. Polymorphonuclear leukocytes released from the bone marrow preferentially sequester in the lung microvessels. Microcirculation 1997; 4: 369-380.
23. Gabrijelcic J, Acuña A, Profita M, et al. Effects of platelet-activating factor on airway neutrophilia and adhesion molecules in mild asthma. Am J Respir Crit Care Med 2001; 163: A595.

24. Jatakanon A, Uasuf C, Maziak W, Lim S, Chung KF, Barnes PJ. Neutrophilic inflammation in severe persistent asthma. Am J Respir Crit Care Med 1999; 160: 1532-1539.

25. Gibson PG, Simpson JL, Saltos N. Heterogeneity of airway inflammation in persistent asthma. Evidence of neutrophilic inflammation and increased sputum interleukin-8. Chest 2001; 119: 1229-1336.

26. Cox G. Glucocorticoid treatment inhibits apoptosis in human neutrophils. J Immunol 1995; 154: 47194725.

27. Duval D, Durant S, Homo-Delarche F. Non-genomic effects of steroids: interactions of steroid molecules with membrane structures and functions. Biochem Biophys Acta 1983; 737: 409-442.

28. Fanta C, Rossing TH, McFadden ER Jr. Glucocorticoids in acute asthma: a critical controlled trial. $\mathrm{Am}$ J Med 1983; 74: 845-851.

29. McFadden ER Jr. Inhaled glucocorticoids in acute asthma. Therapeutic breakthrough or nonspecific effect? Am J Respir Crit Care Med 1998; 157: 777-778.

30. Horath G, Lieb T, Conner GE, Salathe M, Wanner A. Steroid sensitivity of norepinephrine uptake by human bronchial arterial and rabbit aortic smooth muscle cells. Am J Respir Cell Mol Biol 2001; 25: 500-506.

31. Kumar SD, Emery MJ, Atkins ND, Danta I, Wanner A. Airway mucosal blood flow in bronchial asthma. Am J Respir Crit Care Med 1998; 158: 153-156. 